\title{
Money Decentralization under Direct Democracy Procedures. The Case of Classical Athens
}

\author{
Emmanouil-Marios L. Economou, Nicholas C. Kyriazis and Nikolaos A. Kyriazis * \\ Department of Economics, University of Thessaly, 38333 Volos, Greece; emmoikon@uth.gr (E.-M.L.E.); \\ nkyr@uth.gr (N.C.K.) \\ * Correspondence: knikolaos@uth.gr
}

Citation: Economou,

Emmanouil-Marios L., Nicholas C. Kyriazis, and Nikolaos A. Kyriazis. 2021. Money Decentralization under Direct Democracy Procedures. The Case of Classical Athens. Journal of Risk and Financial Management 14: 30. https://doi.org/10.3390/jrfm14010030

Received: 30 November 2020

Accepted: 8 January 2021

Published: 11 January 2021

Publisher's Note: MDPI stays neutral with regard to jurisdictional clai$\mathrm{ms}$ in published maps and institutional affiliations.

Copyright: (C) 2021 by the authors. Licensee MDPI, Basel, Switzerland. This article is an open access article distributed under the terms and conditions of the Creative Commons Attribution (CC BY) license (https:// creativecommons.org/licenses/by/ $4.0 /)$
Abstract: By analyzing the case of Athens during the Classical period (508-323 BCE) the main thesis of this paper is that under direct democracy procedures and the related institutional setup, a monetary system without a Central Bank may function relatively well. We focus on the following issues: (i) The procedures of currency issuing in the Athenian city-state, (ii) why the Athenian drachma become the leading international currency in the Mediterranean world (iii) how and towards which targets monetary policy without a Central Bank was possible (iv) defining the targets of monetary policy and the mechanisms for its implementation (v) the role of money in the economy (vi) the issue of deficit spending (vii) the reasons of the replacement of the Athenian drachma as a leading currency by others from the Hellenistic period onwards (viii) the correlation of our findings regarding the decentralized character of monetary policy in Classical Athens to today's realities, such as the issue of cryptocurrencies. Our analysis shows that monetary policy without a Central Bank was possible, with its foremost aim being the stability of the currency (mainly, silver coins) in order to enhance trust in it and so, make it an international currency which could outcompete other currencies. Since there was no Central Bank like today, monetary policy decisions were taken by the popular assembly of citizens in combination with the market forces themselves.

Keywords: Classical Athens; Athenian currency; monetary policy and institutions; direct democracy; money decentralization; monetary globalization

JEL Classification: E62; F50; G20; G28; N13; N23

\section{Introduction}

According to a vast bibliography, the city-state of Athens established the first ever democratic regime with organized and functional institutions during the Classical period ${ }^{1}$. Furthermore, modern research argues that the ancient Greek economy, and especially that of Athens during this period, was much more sophisticated than it was thought to have been, and was based on a primitive version of free market economic institutions ${ }^{2}$.

After the repulse of the second Persian invasion and the Battles of Salamis (480 BCE) and Plataea (479 BCE) where the Athenians and the other Greeks emerged victorious, the

1 The Athenian Democracy's political system was based on two key institutional bodies, the Ecclesia of the Demos and the Boule. The Ecclesia of the Demos was the popular Assembly, which met 40 (or even more) times per year where every citizen over 20 years of age could vote on any issue under direct democratic-participatory procedures. The Boule members, known also as the Council of the Five Hundred, were elected by lot. The Council was a preparatory body that reviewed the issues to be discussed in the popular Assembly. Its other main function was that 50 Councilmen from each of the 10 Athenian tribes served as government executives (known as Prytaneis) on a rotating basis for one tenth of the year, approximately 36 days. For the political institutions of the Athenian Democracy see, among others, Hansen (1999), Ober (2008) and Tridimas (2019).

2 The trend in the international bibliography of the last 30 years has been to radically revise the older, though influential, views of M. Finley (see e.g., Finley 1973) and his followers who were advocates of the "primitivist" view of the ancient Greek economic organization and institutions. Modern evidence shows that the Ancient Greek economy and more specifically, that of Classical Athens, was much more sophisticated and complex than previously thought and had many modern characteristics. Such evidence is provided, among others, by Cohen (1992), Morris (2004), Amemiya (2007), Bitros and Karayannis (2008), Kyriazis (2009), Engen (2010), Halkos and Kyriazis (2010), Lyttkens (2013), Bergh and Lyttkens (2014), Bresson (2016a, 2016b), Harris (2016), Woolmer (2016), Economou and Kyriazis (2017) and Bitros et al. (2020) and the references they provide therein. 
Athenians formed the Athenian Alliance (478-404 BCE), also known as the Delian League, to continue the war against the Persians, which lasted till the so called "Peace of Kallias" (the Athenian negotiator) in $449 \mathrm{BCE}$. The Alliance gradually changed from a league of independent city-states to an Athenian 'empire' of mainly subordinated city-states, which, at its greatest extent, included 316 city-states (Figueira 1998, p. 52).

Gradually, within the Alliance, a parallel circulation of silver coins from various state mints started to emerge (in Athens, Aegina, Chios, Samos, Rhodes, etc.), leading not only to currency competition, but also to the introduction of common measures for weight and silver content. This not only facilitated the payment of tribute by the allies, but also trade. Free movement of an extensive variety of goods and services, based on market economy principles and a property rights protection environment, was established between Athens and its allies (Woolmer 2016; Economou and Kyriazis 2017). Moreover, Piraeus became the international entrepôt of antiquity due primarily to the huge volume of commercial transactions that were taking place there (Cohen 1992, p. 141; Hansen 2006; Bresson 2016a, 2016b; Woolmer 2016). Thus, the Athenian Alliance was, in some of its aspects, the forerunner of later customs and monetary unions.

In Ancient Greece, the monetary base consisted of currency in the form of coins. In general, in the monetary network that was gradually created in the Mediterranean world there existed a system where coins issued by the various mints of independent citystates circulated as parallel currencies and in competition with one another (Figueira 1998). These coins, with the main denomination being the Athenian tetradrachm (four drachmae), were commonly named glauce (the Greek word for owl). They were of excellent craftsmanship, of high value silver content, stable in their silver value for about two centuries, and thus became the main currency of the Eastern Mediterranean world during the Classical period (Kroll 2011). As discovered hoards show, they circulated from the Black Sea to the Persian Empire, Egypt and Italy and as far as today's France and Spain as a means of exchange for trade, thus becoming an international currency like today's dollar (Kleiner 1975; Van Alfen 2011).

In the following sections we focus on a series of key issues regarding the Athenian monetary policy: The next section analyzes the minting procedure of the Athenian currency. Section 3 examines how the Athenian drachma became the leading international currency in the Mediterranean during the Classical period while Section 4 describes the mechanisms of money decentralization, that is, in our case, how monetary policy without a Central Bank under direct democratic procedures and under a multi-metallic currency system of parallel currencies was implemented in an effective way, as well as the economic implications of the role of money in Classical Athens. Section 5 raises the issue of how Athens managed deficit spending under extraordinary times. Section 6 examines why in the end the Athenian drachma was replaced as a leading currency by others from the Hellenistic period onwards. Section 7 concludes by also relating our findings regarding the decentralized character of monetary policy in Classical Athens to today's realities, such as the issue of the decentralized character of cryptocurrencies.

The main argument of the paper is that although Athens did not have a Central Bank, and even more, a strongly independent Central Bank as in the prevailing current practices (such as the Fed and the ECB), the Athenian economy still proved effective, at least for the longer part of almost two centuries (from the fifth to the fourth centuries $\mathrm{BCE}$ ). We argue that the main reason for the success of Athenian monetary policy was that money supply was determined by a combination of direct democracy procedures in combination with the market forces themselves and the decentralized character of monetary policy.

The paper further shows that the institutional set up of Athens (direct democracy of active citizens) was an important condition for the establishment of a monetary model where the reliability of currency against fraudulent coins was an important prerequisite and was related to the proper functioning of democracy itself. The Athenians had understood the long-term benefits of trust and the reputation of their currency, as against the shortterm benefits of debasement. Thus, the paper further verifies the intertemporal axiom that 
international commercial transactions and networks, in order to flourish, require the use of reliable unadulterated coins of stable value as a means of exchange.

\section{The Minting Procedure}

Athens extracted silver from the mines of Laurion, in the southern part of Attica. Athens coined silver coins, while other city-states coined silver, electrum (a natural alloy of gold and silver) and a few gold coins. Although mining had existed during earlier times, it became intensive and very productive during the fifth and fourth centuries ${ }^{3}$. On the obverse of the coins there was an image of Athena (Figure 1), the guardian goddess of the city, and on the reverse, there was an owl, the sacred bird of Athena, symbol of wisdom. Two kilos of silver were extracted from each metric ton of ore. Gross profit from silver mining in the fourth century has been estimated at about 70 drachmae per ton of ore. Expenses (for enriched ore) were about 38 drachmae per ton leaving a net profit of 32 drachmae (Christesen 2003). As a measure of comparison, the usual daily remuneration for a stone mason working on the Acropolis during the second half of the fifth century was one drachma, and it may have risen to one and a half drachmae during the fourth century (Loomis 1998).
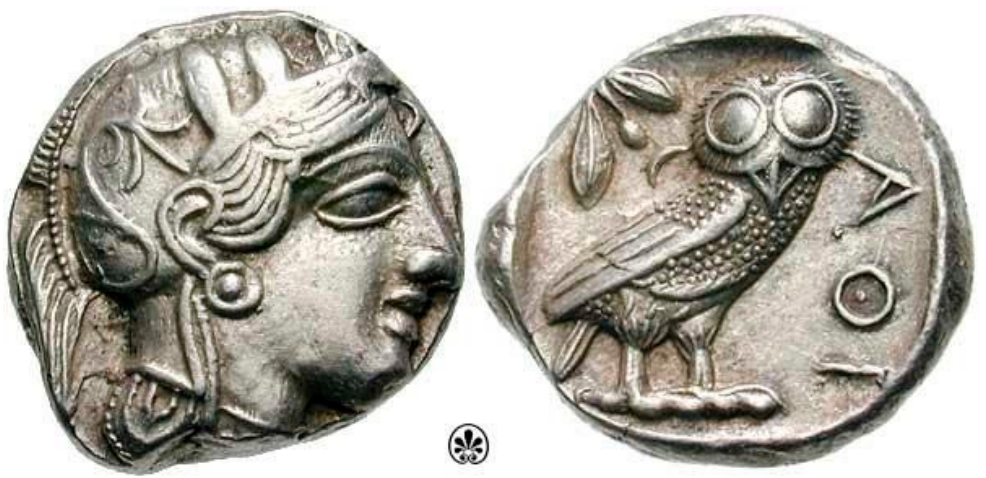

Figure 1. An Athenian tetradrachm. Source: http://www.wildwinds.com/coins/greece/attica/ athens/sg2526.jpg.

The silver resources of Laurion were owned by the city itself. The silver mint, known as Argyrocopeion, also belonged to the state. Possibly it was in or near the Agora, the main marketplace in the city-state of Athens (Kroll 2011, p. 239; Van Alfen 2011, p. 8). Mining operations were privately-run enterprises; individuals or consortia of individuals bid for leases to work particular tracts of the mines offered by a state agency known as the Board of Poletai (board of sellers) (Bitros et al. 2020). The winners were confirmed by the Council of the Five Hundred and thereby received a state contract (Van Alfen 2011). These consortia could be seen as the progenitors of later joint stock companies of Early Modern Europe such as the Dutch and English joint stock companies such as the VOC and the EIC.

The names of 300 mining entrepreneurs are known, showing a relatively wide participation of persons in this activity (Christesen 2003).Various fixed and recurring fees appear to have been associated with these leases, such as a $4.125 \%$ tax on revenue, and rents paid to landowners on whose land silver ores were discovered and mined (Van Alfen 2011, p. 16, $\mathrm{ftn}, 47)$. State taxes and rents amounted to about $10 \%$ of the market value of the extracted silver. The rest belonged to the consortia or individual entrepreneurs, who received their profit in the form of silver ingots (bullion). Then, they could either keep this bullion as their property or they could convert it into coins through the state mint at a discount of about $10 \%$. This covered an estimated cost of minting of about $2 \%$, the remaining $8 \%$ being profit or seigniorage. Alternatively, the entrepreneurs were free to sell the bullion to the

3 For the historical background of Athenian minting see, among others, Kleiner (1975), Figueira (1998), Camp and Kroll (2001), Christesen (2003), Schaps (2004), Kroll (2011) and Van Alfen (2011). 
highest bidder in a free market (Van Alfen 2011, p. 19). The earnings from mining were variable, depending on "luck". If the investor(s) discovered a rich vein of ore, their profits could be remarkably high. The Athenian state was very strict in the control and auditing of officials involved in monetary affairs. The operations of the Athenian silver mint were directed by a Board of Epistatai (supervisors) whose members were public magistrates and served for fixed terms (Bitros et al. 2020).

Furthermore, due to the realization that there was insufficient money circulating in small denominations to cope with daily retail transactions such as buying small-valued items like bread, the Athenian state issued the so-called obols, made from silver, which were lighter in weight and smaller in size. One drachma was equal to six obols. Even smaller denominations of coins were introduced, to facilitate the large volume of small value transactions. These bronze coins, known as chalkoi and kollyboi were issued by the private sector (Kroll 1993) ${ }^{4}$. Thus, at least for the fifth century, the private sector covered a need not covered by the official mint. One reason that the state did not issue bronze coins may have been the fact that it did not have the capacity to do so (insufficient qualified personnel for the production of low-value coins) and that the cost incurred in relation to any seigniorage was deemed to be too high to make the production of bronze coins by the state mint worthwhile.

However, Camp and Kroll (2001) have identified a structure in the Agora as a second state mint, used for bronze coinage, known as Nomismatocopeion. It started minting coins (probably under state supervision) possibly in the early fourth century. A part of the volume of production of bronze coins, should be attributed to this state bronze mint. Thus, in this case, we see a kind of specialization of each sector: silver coins issued by the state, bronze issued mainly by the private sector. This, again, is one of the earliest examples of the issuing and circulation of private coins, which are common in electronic form in the 21st century (Bitcoin, Ethereum, and more than 1600 types of electronic coins in total).

\section{Why the Athenian Drachma Became the Leading International Currency during the Classical Period}

A first key reason the Athenian drachma became a leading international currency in the Mediterranean during the Classical period is that currency competition within the Alliance, and also outside it, favored currencies issued by larger economies, because this was related to the size of these economies ${ }^{5}$ and their trade. This lowered information and transaction costs in general for those using these coins since these coins were more easily recognized, and the users had a clear perception as to their silver content and thus, as to their value. Because of currency competition, electrum coins were gradually replaced by silver coins because the monometallic content of silver coins could be more easily evaluated than the bimetallic content of electrum coins. This made it easier to calculate their value, thus lowering transaction costs. In addition, the die (stamp) of a state mint was a guarantee of value and this justified a degree of seigniorage.

A second key factor for the establishment, evolution and success of such a beneficial environment for interstate trade is related to the so-called Coinage Decree of Athens which made the acceptance of the Athenian drachma mandatory within the Alliance but did not prohibit the minting and circulation of local currencies. The actual Coinage Decree has been discovered on two separate stone inscriptions and since then has caused ongoing discussions. Some historians have interpreted it as prohibiting the use and circulation of other currencies within the Alliance. However, Figueira (1998, pp. 310-411) interpretation that the Decree introduced common weights and standards and made the Attic drachma the leading international currency but did not prohibit the minting of coins by other mints and the parallel circulation of their coins seems very convincing. Figueira (ibid., p. 176)

4 The reader can confirm the existence of a wide range of these coins, among others, through the following hyperlinks: https://www.wildwinds.com/ coins/; https://www.cngcoins.com/; https://www.vcoins.com/en/coins/ancient/greek-593.aspx.

5 What we call GDP today. 
argues that after the Decree, there were at least 11 and possibly as many as 24 mints still in operation in allied city-states, which proves that the Decree did not forbid the minting of coins by non-Athenian mints. Furthermore, continued currency competition kept seigniorage at relatively low levels.

A third factor is related to the so-called Nicophon's Law. Sometime later, in 375/374 BCE, the Athenian Assembly voted in favor of Nicophon's Law which mandated that counterfeit or fraudulent coins were to be seized, withdrawn from circulation and demonetized, thus guaranteeing once again the value of the coins and the trust of users. Under this law, the parallel circulation and acceptance of good foreign coins was permitted in Athens (Engen 2005; Rhodes and Osborne 2003, p. 115; Bitros et al. 2020). To implement the law, two public slaves were introduced, known as 'testers' (dokimastai), who had a bench in the Agora of Athens and at the harbor of Piraeus and examined foreign currencies to check if they were fraudulent. If one of the private contracting parties had doubts regarding the purity of the foreign coins, he could bring them to the 'tester' to be examined. If found impure, the coins were confiscated, then cut through immediately and became the sacred property of the treasury-temple of the Mother of the Gods, which was one of the Athenian Treasury-Temples ${ }^{6}$. If found to be authentic copies of the Athenian drachma, (meaning that they were of the proper silver content) they were returned to their owners, who then had the right to use them legally in order to conduct commercial transactions in the market (Engen 2005; Rhodes and Osborne 2003, p. 115). The parallel circulation of currencies was a measure for reducing transaction costs and thus increasing trade coming to Piraeus (Ober 2008, pp. 222-25, 237).

The Coinage Decree and Nicophon's Law significantly strengthened the position of the Athenian drachma as the universally accepted currency in the Eastern Mediterranean. Through the establishment of the Athenian drachma as the leading international currency among its allies and other states the Athenians achieved the establishment of a unified economic area of commercial transactions which was beneficial to their strong economy. Interstate trade in this vast area was developed between Athens and its more than 300 allied city-states as well as with other non-Alliance member city-states). For example, Isocrates (1980, pp. 4, 42) proudly proclaimed that there was no good produced anywhere in the world that could not be found in the port of Athens. The territory of Attica was rich in a great variety of products such as cheese, honey, hides, wool and charcoal and Athens had expertise in various sectors of production, such as olives, honey, ceramics, etc. Athenian exports comprised olive oil, Hymettus honey, some wine from the agricultural sector, but more significantly, handicraft and "industrial" products, like pottery, furniture, silver plates, marble and bronze statues, iron and bronze domestic utensils, arms and jewelry (Halkos and Kyriazis 2010).

Trade was developed to such a magnitude that, according to Hansen (2006, p. 92), in 402/401 BCE, the import and export trade of Athens, including transit trade must have been more than 1800 talents, which was equal to 10.8 million drachmae since one talent was equal to 6000 drachmae. This was a large sum and is a proof of the commercial dynamics that had developed between Athens and its allies. Trade was highly beneficial to Athens since it promoted economic development and provided employment for substantial parts of the population in commerce, shipbuilding, and other services related to trade etc. It was also an important revenue source due to the $2 \%$ customs duty on exports and imports known as pentecoste (Kyriazis 2009; Halkos and Kyriazis 2010; Harris 2016; Woolmer 2016, p. 70).

\section{Money Decentralization under Direct Democracy Procedures in Decision Making}

The Athenian citizens had to decide in the popular Assembly as to the proper quantity of money supply that should be produced by the silver mint so as to cover the annual

6 For the Treasury-Temples of Athena and the Other Gods see more details in Section 5. 
needs of the state (Figueira 1998). Thus, issues of monetary policy were introduced to and decided by the Assembly under direct democracy procedures (Bitros et al. 2020).

This is a major difference with today's situation in which monetary policy is entrusted to non-elected experts and "nonpolitical" bodies like the Central Banks which (in principle) are independent of political manipulation. And since the Athenian drachma became a universal coin in the Eastern Mediterranean, Athenian citizens showed remarkable restraint against the temptation to adulterate its silver content, when even a minor debasement would have reaped appreciable benefits, given the size of coins in circulation. It seems that Athenians were conscious of the long-term benefits of trust in and reputation of their currency, as against the short-term benefits of debasement. A characteristic proof of this is Aristophanes (1994, p. 718) who strongly criticized the phenomenon of currency debasement. Furthermore, Demosthenes (1939, p. 24.212) argues that whoever tried to promote fraudulent coins in the market was put to death by law, which was the most severe penalty in the Athenian state. This further signifies how important it was for the Athenians to secure that their national currency would not be forged. They considered that if this happened it could undermine the proper functioning of the Athenian state itself; it could harm the society's affluence, so it was worth imposing the heaviest punishment to the offenders.

\subsection{How Was the Money Supply in Classical Athens Determined?}

Taking the above into account, an important issue arises: how was the money supply in Athens regulated? As we argue below, money supply arose from two sources: the state and the private sector. Regarding the first, the city-state of Athens, through its 'budget', had to pay for the armed forces, the navy (construction of ships and payment for crew), cavalry and infantry, construction and maintenance of fortifications and public buildings such as temples. It also had to cover the costs of the administration, which included the remuneration of the participants of the Assembly which required a quorum of $6000^{7}$, payment to members of the Council of the Five Hundred, other administrators, approximately 700 public magistrates who worked in various government agencies such as street cleaning, policing, the water supply, maintenance of the city's walls, maintenance of the city's temples, etc. Other payments that had to be made were to the members of the Heliaia popular courts, the cost of the education of orphans whose fathers were lost in war, to foreign embassies, etc. (Hansen 1999; Kyriazis 2009; Bitros et al. 2020). All these payments were made in silver currency, so the supply of coins had to be enough to cover these expenditures.

The second source of money supply derived from the private sector in order to cover daily exchanges in the market, for trade and for citizens to be able to pay the costs of liturgies $^{8}$, taxes, customs duties, etc. Money supply could be further increased by the melting and monetization of silver bullion held by private agents. The monetization of silver bullion shows a solid intuitive understanding of economics since the Athenians knew that they could influence money supply by altering the terms under which the state mint accepted old (worn out) coins and bullion held by private agents, for re-striking, by lowering the cost if they wished to increase supply and vice versa. Anyone who had silver bullion might convert it into drachmae at a small fabrication and seigniorage cost.

For example individuals or consortia of individuals who had been granted by the state the exploitation of areas in the silver mines of Laurion through land lease (as mentioned in Section 2) could use the bullion they earned by converting it into currency through the Athenian mint (Bitros et al. 2020). They could then use this currency for various economic activities, such as payments and of course this new amount of money that was being

7 The Athenians had introduced a reimbursement of three obols (half a drachma) to those attending the Assembly meetings, so as to make possible also the participation of poorer citizens. This was increased later to one drachma (Hansen 1999).

8 Liturgies were a special type of taxation through which a wealthy man, and later a group of men, undertook to finance the provision of a public service, such as the maintenance of a warship, known as the process of trierarchy or the cost of religious festivals, the cost of theatrical performances etc. (Lyttkens 2013). 
circulated into the economy was essentially a process of increasing the money supply caused by the market forces themselves. Thus, in actuality, the mint undertook a function which looks similar to modern Central Banks practices, in terms of influencing liquidity through their interest rate (discounting) for the acceptance of bullion. The main reason for citizens who held bullion to monetize it, was to cover their (especially non-permanent) tax obligations, liturgies, or other extraordinary expenses, for example a marriage festivity, the granting of a monetary dowry for a daughter, etc.

In accordance with the above, a third way of influencing money supply by the private sector was by issuing small-value bronze coins by private persons as described in Section 2. Fourth, war booty in the hands of Athenian privates was also a potential means of increasing the money supply in the economy, even if in an 'unorthodox' way (Günther and Hahn 2019).

A fifth source of influencing the money supply should be attributed to the existence of banks. The establishment of the twin city of Athens and Piraeus as a major international trade center of the Mediterranean is also related to banking activity. In Cohen (1992) seminal work Athenian Economy and Society we learn that by the fourth century the Athenian state had a functional banking system, providing a series of advanced (for the era) banking services such as: (i) accepting deposits (ii) carrying out payments on behalf of their customers (iii) providing loans to a plethora of business operations, including maritime loans and even consumer credit financing (iv) exchanging local with foreign currencies (v) settling payments among importers from abroad and exporters to merchants abroad (vi) providing insurance services (vii) providing consultancy to important customers (viii) providing collateral, for example, of the ship in the case of maritime loans (ix) accepting valuables and documents for safekeeping (however, they did not act in the capacity of pawnbrokers) (x) helping wealthy Athenians and foreigners to conceal a part of their property so as to escape taxation (like today's offshore services).

The ordinary interest rate for someone who borrowed money from a bank varied between 12 and 18\%. By contrast maritime loans could be as high as $100 \%$ due to the great uncertainty of maritime trade and the safety of the cargos, even if insurance services were also an option for maritime traders (ibid., pp. 140-42). Thus, interest rates varied according to the type of activity. Cohen (ibid., p. 31) states that in Classical Athens not less than 30 bankers are attested by name. The available information we have does not allow an estimate of the contribution of the banking system to employment and GDP, however, there is no doubt that due to the fact that all these bankers were heavily engaged with the commercially oriented aspect of the Athenian economy on the 'international' level, their contribution to the functioning of the Athenian trade and economy was important ${ }^{9}$. Since Athenian commercial banks did give credit, we assume that they increased the overall money supply in the economy. However, we do not have statistical evidence/cliometrics data available to calculate the size of the money multiplier and in general the effect of money supply by the banking sector.

Finally, as will be further explained in Section 5, the Athenian state could borrow money from the so-called Treasury-Temples in order to finance military or other state expenses. This was another indirect way of increasing the money supply in the market.

\subsection{The Economic Implications of the Role of Money in Classical Athens}

The examination of the Athenian monetary policy could be conducted under a spectrum of further perspectives that are related to the overall role of money in the Athenian economy. An interesting theoretical issue is if the Athenian drachma was accepted as the

9 Due to space limitations we do not analyze the Athenian banking system more extensively here since this has been done in convincing detail by Cohen (1992). See also Amemiya (2007, pp. 87-103), Goetzmann (2016) and Bitros et al. (2020) among others. 
leading international currency for the era due to its proper silver content rather than because it was issued by a state authority ${ }^{10}$.

First of all, a comment should be made regarding the gap between the fundamental value and the nominal value of issued coins. Notably, the decentralized character of Athenian currency (due to the absence of a Central Bank) prevented the formation of bubbles regarding the currency value. In contrast to the highly-inflationary phenomena of today where monetary authorities print large quantities of money in order to finance public debt, the decentralized character of currency issuing in Classical Athens provided an inflationary backstop and prevented manias and subsequent crashes based on abrupt increases and decreases of currency values. According to modern theory (Bell 2001), money can be employed as credit (chartalistic character) rather than as a value-preserving asset (metallistic character).

The main advantage of decentralized coinage creation in Classical Athens was that the benefits from chartalism (facility to trade and to conduct transactions) were combined with the ability to confront inflationary pressures, as the fiscal authorities could not exert pressure on monetary authorities to print more money during stressed eras.

Moreover, money decentralization in Classical Athens can be examined through the perspective of monetary transmission channels and wealth effects. According to modern theory Joyce et al. (2012) present the portfolio rebalancing channel as a mechanism of substitution between alternative assets. This was an intense phenomenon in ancient times as the alternative means of liquidity available (as described above) ${ }^{11}$ and the parallel currency circulation regime enabled interested economic units to substitute one type of currency for another that was more suitable for their transaction needs. Furthermore, the expectations channel ${ }^{12}$ was also functional in Classical Athens even without the presence of a Central Bank, since the existence of a range of alternative currencies that could circulate in the Athenian economy lowered expectations about interest rates of lending money through the banking sector. Consequently, this spurred economic growth ${ }^{13}$ due to economic agents being aware that it would be highly unlikely for shortages of liquidity to emerge. In other words, alternative currency offered ease in conducting transactions and therefore this policy reduced transaction costs.

It could be further claimed that the decentralized character of multiple money creation in Classical Athens was beneficial for lowering the interest rate required for investors and consumers. Nevertheless, based on the literature we provided above, it could be argued that Athenian coins contained higher portions of bullion than almost any alternative coins that were minted in other regions. Thereby, the most preferred coins were also the most valuable ones in terms of intrinsic value. This can lead to the conclusion that no opportunities for speculation emerged, as the lack of a bubble character in coin values did not allow economic units to take advantage of misperceptions about the value of coins.

\section{How Athens Managed Deficit Spending under Extraordinary Times}

During periods of financial difficulties and deficit spending due to extraordinary situations, as by the end of the Peloponnesian (431-404 BCE) and Social Wars (357-355 BCE), money supply could be further increased by issuing electrum coins (which were phased out during the first half of the fifth century) as well as gold, bronze and silver-plated (with a bronze core) coins.

A characteristic example is the melting down of public holdings of gold, especially that of the gods' treasuries. The first gold coins were minted in $407 \mathrm{BCE}$, by the melting,

10 Obviously, such a discussion, if expanded, could be seen through the well-known debate regarding metallism vs chartalism. Such an issue deserves a detailed separate analysis, however, due to space limitations we won't expand more than the evidence we provide below.

11 Money creation by the private sector (silver bullion, bronze small value coins, money creation by banks, war booty) and the treasury-temples.

12 Regarding monetary policy transmission with emphasis on the expectation channel see Williams (2011) and Abbassi and Linzert (2012).

13 It is verified that during the Classical period Athens achieved economic growth (Morris 2004; Ober 2015; Bresson 2016a; Harris 2016; Woolmer 2016) although relatively slow by some modern standards. 
among others, of seven gilded Nikai (Victory) statues. Furthermore, private individuals sold their silver and gold plate to procure tetradrachms in order to pay taxes and subsidize their military service. Inflow of gold pushed down its relation (exchange rate) to silver. Supply of gold increased due also to the Persian subsidies (in gold Daric coins) given to the Peloponnesians. The exchange rate of silver to gold fluctuated according to demand and supply, as demand for coins, bullion and for private use (jewelry, etc.) varied. The exchange rate fluctuated during the 434-397 BCE period (Figueira 1998, pp. 511-21).

Thus, by the end of the fifth century, in Athens and the Alliance, there was a fourelements metallic system in operation: silver, silver-plated, gold and bronze coins. However, what is important is that the Athenians were conscious of the necessity of protecting the reputation of their currency, and the trust in it of both the Athenian and foreign public. Thus, they undertook deliberate efforts to avoid an incremental debasement of the main series of drachmae and tetradrachms. A further indication of the Athenian consciousness was that very soon after the end of the Peloponnesian War and the restoration of democracy, silver-plated and gold coins were retrieved from circulation and demonetized. Athens reverted to silver coins as its legal tender (ibid., pp. 510-11). Another characteristic example is the so-called Social War (the secession of its allies from the second Athenian Alliance) when Athens experienced financial difficulties. The state's revenues plunged to 130 talents per year and Eubulus, the leading politician and chief manager (tamias) of the so-called Theoric Fund at the time ${ }^{14}$, proposed in the Assembly extraordinary measures to increase revenue. Among them was a decree ordering the recoinage of older coins and the issuing of new ones to replace them.

During extraordinary situations that forced the Athenian authorities to deficit spending, the Athenian state had a second important policy available to exit from the crises. It could resort to borrowing and finance its debts through the so-called Sacred Funds known also as the Treasury-Temples of Athena and Other Gods. These Treasury-Temples collected money from the payment of fines, rental of property owned by the state, money from the faithful and even private donations. The Treasuries of Athena and the Other Gods were very substantial due to their financial strength. That of the Goddess Athena, the treasury with the largest financial capacity among all others in $431 \mathrm{BCE}$, at the beginning of the Peloponnesian War, was valued at 6000 talents, half of it was in Attic silver coins and the rest in foreign silver, electrum and gold coins. These treasury-temples were united into one in 406/405 but were separated in 384. They were reunited permanently in $346^{15}$. The Treasury-Temples were neither private nor 'pure' public institutions and, typologicallyinstitutionally speaking, they could be characterized as 'public legal entities' or quasi-state institutions that is, their main purpose was to conduct specific functions or services in favor of the state.

The proceeds created by the Treasury-Temples could be given as remittances to the state when it needed to borrow. For example, part of this money could be borrowed by the state to maintain and repair public buildings. During times of war, Athens borrowed massively from the treasuries and mainly from that of the goddess Athena on the Acropolis. After the wars, these loans plus interest were repaid through budget surpluses. More specifically, the Temple of Athena till 427 BCE loaned money to the state at an interest rate of $6 \%$ but only $1.2 \%$ from 426 BCE onwards (Blamire 2001, p. 108; Rhodes 2005, p. 93). Ancient sources or modern evidence do not explain why the interest rate fell from $6 \%$ to $1.2 \%$. It is reasonable to assume that this happened because the high cost of financing the Peloponnesian War made the Athenian state authorities to force the Temple of Athena to accept lower interest rate than before.

14 Eubulus used this post to gradually take control of the finances of Athens which led to a degree of prosperity not seen in many years (Rhodes and Osborne 2003, pp. 157, 464, 467). The Theoric Fund was related to money given mainly to poor citizens to participate in public events of the city (theater, gymnastic contests, and games, etc.). Before every event, each citizen would receive two obols a day so as to be able to participate in the event (Hansen 1999).

15 The analysis of the institutional organization of the Treasuries of Athena and the Other Gods exceeds the purpose of this paper. An extensive analysis of this is provided by Blamire (2001), Van Alfen (2011) and Bitros et al. (2020) among others. 
When the state borrowed from the treasuries, it put back into circulation money which the state had left for safekeeping in the treasuries of the gods, thus increasing the money supply in the economy. In this way, the treasuries functioned as a kind of a quasi-Central Bank in the way Central Banks functioned for some states (e.g., Greece before joining the EMU), lending to the state sums in order to cover budget deficits, a case of monetization of deficits leading to inflation. This again could explain the very low interest rate (1.2\%), which was presumably set by the Council of the Five Hundred or the chief manager of the public revenues known as tamias epi tis dioikiseos ${ }^{16}$.

Here we must mention that, after the defeat of Athens in the Peloponnesian War and the restoration of democracy, the Assembly decided in 403/402 BCE to write off outstanding debt to the Treasury of Athena. But the Athenians, understanding the necessity of trust and reputation, never repeated this extraordinary measure.

\section{Why the Athenian Drachma Was Replaced as a Leading Currency by Others from the Hellenistic Period Onwards}

In Section 3 the question of why the Athenian became the leading 'international' currency during the Classical period was analyzed. In connection with Section 3, this Section deals with the main reasons the Athenian drachma did not manage to maintain such a privilege in the following centuries. This discussion may be seen as an interesting historical lesson with intertemporal policymaking extensions that reach even the current realities, for example, the current policymakers who deal with modern monetary union economic policies, such as the Eurozone and the ECB.

From the analysis in Section 3 it can be argued that due to the implementation of the Coinage Decree (even if with relative success) and the Nicophon's Law (with success), the Athenians managed to establish an economically-commercially unified area between (at least) the city-states which belonged to the Athenian Alliance, with the Athenian drachma being the leading international currency for performing a large (or the largest) volume of such transactions. Unfortunately, due to the lack of cliometric data we cannot measure the exact percentage of the volume of the 'international' trade that was taking place through the usage of Athenian drachmas in relation to the total. What is for sure is that in parallel to the Athenian Alliance, the same member-city-states also formed an ad-hoc monetary union where Athens had the leading role.

Networks of cooperation for the rise of maritime trade in the Aegean gradually developed from the Archaic (750-508 BCE) to the Classical periods and were further developed in the Hellenistic period (322-146 BCE) (Constantakopoulou 2007; Mack 2015). Furthermore, the emergence of federal states such as the Achaean and the Aetolian leagues increased further the magnitude of interstate commercial cooperation by establishing viable and functional monetary unions and networks of economic cooperation (Economou and Kyriazis 2017; Economou 2020). Jarde (1996, p. 255) characteristically writes the following:

'When a single city exercised hegemony over a whole group it was careful to obtain, by persuasion or force, the adoption of its own means. Thus the Attic system became that of the whole maritime confederacy. Money, in the same way, acquired an international value ... Each city had its mint which struck coins bearing the emblem of the city. But, as in the case of weights and measures, there was a movement towards unification ... Above all the importance assumed by the trade of certain cities and the good alloy of their currency caused certain coins to be accepted on every market. The money of Aegina, Corinth, Phocaea, Cyzicus and Lampsacos had international value... '.

Interstate monetary unions either through Alliances (such as the Athenian) or through federal leagues (such as the Achaean, and the Aetolian) were backed up by a series of insti-

16 Known also as the epimeletes tis koines prosodou, a post with duties more or less similar to that of a modern finance minister. The office was introduced during the fourth century and due to the fact that the tamias had to be a financial expert, he was elected annually by vote and not by lot (Bitros et al. 2020). 
tutional arrangements which were tested in practice through trial and error and proved effective. These institutions that boosted 'international' commercial activity included, among others, an effective regime of property rights protection (Economou and Kyriazis 2017), interstate banking activities (Cohen 1992) backed up by insurance services so as to secure international trade transactions (Acton 2014) and institutions such as proxeny (a system of developing diplomatic relationships between states), asylia (exemption from reprisals from one city-state to another) and isopoliteia (political equality $)^{17}$.

Then, since Athens had established a functional version of an ad-hoc monetary union, a critical question arises: why was the Athenian drachma surpassed as the leading international currency during the Hellenistic period that followed? In fact, although this is a very interesting question, it is probably quite complicated and due to space limitations, it exceeds the purpose of our paper. However, we think that it is imperative to provide a concise answer to this point since it may contribute to better understanding of historical events that characterize the general rise and fall of monetary unions ${ }^{18}$.

Based on the existing evidence and the elaboration that follows, we think that the reasons that other currencies displaced the Athenian drachma as the leading currency should be mainly attributed: (i) to the fact that that the issuing monetary authority of the new successor leading currency, the Macedonian tetradrachm (four drachmae) took care to keep the value of the currency intact and to avoid devaluations of its value, as far as possible, as was also the case with the successful preexisting paradigm of the Athenian drachma (ii) the military realities and the geopolitics of the time.

In particular, after the land defeat of the Athenians and their allies at the Battle of Chaeronea in 338 BCE and the major defeat of the Athenian navy at the Battle of Amorgos by the Macedonian one in $322 \mathrm{BCE}$, Athens declined, and just a bit later it became a satellite state of the Kingdom of Macedon, at least for a period of time (Habicht 1999). On the other hand, the Kingdom of Macedon was the mightiest military machine of the Hellenistic times and through the conquests of Alexander III the Great, the Hellenistic world was created, including a vast area from the Balkans to Ancient India (today's Pakistan).

Elliot (2018, p. 6) writes that after Alexander's death in 323 BCE, his successors, generals, governors and soldiers waged war for his legacy for nearly a quarter of a century. In each of these successor kingdoms coins were issued in the royal mints-most of them struck in the name of Alexander the Great. As a result of the vast number of soldiers, hired in the wars between the successor kingdoms, gold and silver coins issued by the mints of the successors, flooded the Eastern Mediterranean and beyond. This explosion of gold and silver in the late fourth century BCE led these so-called Macedonian tetradrachms or staters to surpass the Athenian tetradrachms.

Furthermore, as Elliot (2018, p. 8) adds, the political fragmentation that occurred after Alexander's death aided in the creation of currency zones. For example, one of these currency unions included the city-states in the Meander valley in Asia Minor (today's Turkey), such as Magnesia, Priene, Naulochos and Antioch (Thonemann 2011, p. 37).

These developments did not mean that the Athenian drachma and other Greek-made coins were wiped out of circulation. Eminent numismatologist J. Kroll (1993) provides tangible evidence that the Athenian drachma, even though it was not the leading international currency, was still circulated not only during the Macedonian-Hellenistic but also during the Early Roman period. Some Macedonian successor kingdoms used Athenian weight standards for their distinct coinages, but others created their own coin denominations and enforced the use of their coins through legal tender laws. The first and most notable of these currency systems was the one created in Egypt under Alexander's general, Ptolemy I Soter and his successors. Although cases of currency devaluation due to a political decision

17 Economou (2020) analyzes in detail how these institutions functioned in practice.

18 In fact such an issue is generally related to how monetary unions are historically created, developed, flourish and finally collapse. For example, one may seek parallels with later historical cases such as the Wendish Monetary Union, the German Zollverein and the current Eurozone. We promise an analytical elaboration towards this direction in a future paper. 
by the kings were real, such as the Ptolemaic tetradrachms who lost roughly $25 \%$ of real assets in silver, the general rule is that the Macedonian successor kings had understood that their national currencies could become leading international currencies only if they followed the Athenian 'golden rule', which was: (i) not to devaluate in principle the coin, (ii) taking measures against forgery. Mørkholm (1991) conveys such a view.

In other words, what is also important to bear in mind is that the Macedonian tetradrachms became the leading currencies in this vast economic unified area and displaced the Athenian drachma from this privilege, not only due to geopolitics and the rise of Macedon, but also due to the superior characteristics of these Macedonian coins, which were similar and obviously, competitive to those of Athens. These superior characteristics included: (i) being made by high quality of either gold (mainly) or silver (ii) being not fraudulent at any cost (iii) the engravings with the marks of the kingdom that cut them to be clear and easily recognizable by those who used them for transactions. These characteristics made the Macedonian tetradrachms generally desired because they facilitated transactions and limited the transaction costs between merchants when trading with them.

This is also true for the Roman period that followed. Sometime before the end of the Second Punic War (218-202 BCE), the denarius system of Roman coinage quickly came to dominate Italy and Sicily, pushing the various Greek silver coinages out of circulation and as Elliot (2018, p. 8) writes, the new monetary system seems to have been partly successful due to the military mints set up in Italy, Sicily and Sardinia, which would have overwhelmed these areas with coins on the Roman standard. Even the monetized cities of Southern Italy with their long tradition of Greek coinage standards abandoned these systems and began using denarii and asses types of Roman coinages. The spread of denarius should be attributed also to the growth of cities in Italy and their demand for surplus goods produced in the countryside (p. 8). On the other hand, it should also be acknowledged that the denarius was enforced in the Greek world, for taxation payments purposes only, after the Augustus imperial period onwards (p. 10).

As a final comment, Elliot (2018, p. 12) acknowledges that the Romans gradually managed to create a somewhat interconnected monetary system in the process but it seems that the intended roles of money in the Roman Empire were almost entirely practical: paying troops, exercising power and displaying status. Thus, here again we observe that, to some degree, the denarius was (actually) imposed in the entire Roman world in order to satisfy geopolitical necessities of the time, that were related to the Roman supremacy. What is also important to bear in mind is that the decline of the denarius as a legal tender started as soon as debasement acts started taking place such as Nero's debasements in 190's (Butcher and Ponting 2005).

These findings drive us to the last part of our argumentation, which is to provide some evidence regarding currency issuing in the Byzantine empire This comes as a supplementary analysis to the Roman Empire's findings since the Byzantine Empire was the successor to the Roman one, its eastern part ${ }^{19}$. The Byzantine currency was called solidus and it is also known as the bezant. It was introduced in $301 \mathrm{AD}$ on a large scale, under Emperor Constantine, the Great. It had a weight of about $4.5 \mathrm{~g}$. For about 800 years solidus dominated the known markets of the world. From its establishment until the 11th century, it remained unadulterated and acquired a mythical glamor. In monetary history it remains the successor of the ancient 'international', Athenian and Macedonian drachmae and the 'internationalized' Roman denarius, which completed its historical cycle at the beginning of the 4 th century (in 313 its cuts stopped).

Like any powerful currency that plays its role, solidus dominated the domestic and foreign markets, giving the Byzantine Empire unlimited power and wealth. It started to be debased after $1025 \mathrm{AD}$ and perhaps it is not a coincidence that the decline of the Byzantine Empire as a political entity also started from that period onwards. Solidi circulated normally

19 The Eastern Roman Empire was gradually evolved into the Byzantine, starting with the transfer of the capital of the Roman Empire to Constantinople. 
until the end of the 13 th century, with variations in weight, hence the value. From time to time various designations were added to their name.

As a general assumption on the analysis of this Section, it can be argued that, historically, ad-hoc monetary unions can be successful providing that: (i) they take measures so as to keep the value of the currency intact and to avoid devaluations of its value, as far as possible (ii) when the issuing monetary authority comes from a state which is strong in geopolitical and military terms.

\section{Conclusions}

The main thesis of the paper is that under direct democracy procedures and the related institutional setup, a monetary system without a Central Bank may function relatively well. Column 2 in Table 1 summarizes all the evidence regarding the operation of money in the Athenian economy. The Athenian currency was well-established and recognized as an international means of exchange and was strong enough to dominate the Athenian and, to a great extent, the Mediterranean market without official support in the form of extensive regulation. The Athenians had faith in their currency and understood that the best way to safeguard its reputation and international acceptability was not through restrictions ("capital controls" in today's terminology) but by generating trust. This was achieved by keeping the value of silver of the coins unadulterated, only excepting extraordinary circumstances such as the Peloponnesian War.

Table 1. The operation of money in the Athenian economy.

\begin{tabular}{|c|c|}
\hline \multicolumn{2}{|r|}{ Monetary Policy } \\
\hline Type of money & $\begin{array}{l}\text { Intrinsic value currency: mainly silver (but also bronze, and, in some extraordinary instances, } \\
\text { silver-plated or gold) }\end{array}$ \\
\hline Money supply mechanism & $\begin{array}{l}\text { The quantity of money to be produced by the state silver mint had to be decided and approved } \\
\text { by the popular Assembly and Council of the Five Hundred. This was a direct democratic } \\
\text { procedure related to the will of the people. } \\
\text { The supply of money was determined by altering the terms under which the state mint } \\
\text { accepted old (worn out) coins and bullion }\end{array}$ \\
\hline $\begin{array}{l}\text { Further means of affecting } \\
\text { money supply }\end{array}$ & $\begin{array}{l}\text { - Privates could convert silver bullion to coins and then use them for performing a series of } \\
\text { - } \quad \text { Privates or consortia of privates could issue small value bronze currency } \\
\text { - Issuing of silver-plated, gold and bronze coins in exceptional circumstances such as war } \\
\text { - } \quad \text { Banks } \\
\text { - The State could borrow from the Treasuries of the Gods } \\
\text { - War booty }\end{array}$ \\
\hline Supervision and auditing & $\begin{array}{l}\text { By the State through the institution of the 'testers' (dokimastai). This institution was supervised } \\
\text { by the Council of the Five Hundred and the Assembly }\end{array}$ \\
\hline Parallel circulation of currency & $\begin{array}{l}\text { The Athenian drachma became the main "universal coin" during the Classical period among } \\
\text { other currencies circulated within the Athenian Alliance and elsewhere, such as those of } \\
\text { Aegina, Chios, Samos, Rhodes, etc. }\end{array}$ \\
\hline Unadulterated value of currency & $\begin{array}{l}\text { - The best guarantee of sound money } \\
\text { - } \quad \text { A basic principle of the Athenian international monetary policy strategy }\end{array}$ \\
\hline
\end{tabular}

The Athenian drachmae, being of excellent craftsmanship and of high and stable silver content, became the main currency of the Eastern Mediterranean world for about two centuries. The Athenians understood further that the parallel circulation of currencies was not a threat but an opportunity to facilitate exchange and trade and attract more trade and production capacity in Attica. Under such a "globalized" environment in the Eastern Mediterranean during the Classical period, we know that Athenian banks attracted foreign "capital", offering services such as accepting deposits, providing loans, keeping bank deposits, providing insurance to commerce such as cargo ships and even something 
similar to today's offshore services. Part of this capital was invested, through loans in production and services, agriculture, manufacturing, mining and shipping.

Even more important and challenging are some further issues that can be drawn from the overall previous discussion, such as (i) the issue of the procedures for the adoption and implementation of monetary policy measures (ii) the issue of centralized central banking vs. decentralized (iii) as an extension of (ii) the potential use of bitcoins (even if some are a bit speculative), (iv) the issue of disconnecting dollar from gold ${ }^{20}$.

Regarding (i) here, there is a great difference between Athenian and modern practices. As we have analyzed, under Athenian direct democracy, the citizens, through their vote in the Assembly, were the ultimate decision-makers for monetary policy, the safeguard of the currency's reputation and, finally, for the auditing and control of officials who could be accused at the citizen's courts if they did not fulfill their functions in a proper manner. These were "experts", introducing proposals for monetary issues, like Nicophon, and "experts" like the fourth century tamiai who administrated economic issues, both monetary and financial, that were interlinked. However, the "experts" had to convince the Assembly and were controlled by it, through a democratic process. However, as we have analyzed, in practice, the final outcome of the annual quantity of money circulating in the economy was determined by a combination of the Athenian Assembly's decisions and the functioning of the market forces themselves.

Athens did not have a Central Bank, although it had a "national" silver mint. The private sector's banks were not controlled by any state body. Therefore, there was no Central Bank monopoly. With very few modern exceptions, like the Swiss case, authority for monetary policy in modern states is delegated to "experts" such as the Central Bank, which has the monopoly in decision-making on monetary issues. This again raises a general issue for modern democracies, in which Independent Regulatory Bodies (as, for example, telecommunication, energy, etc.) seem to proliferate, as against the ancient Greek Athenian practice where decisions regarding state (and monetary) policy issues in general were taken under democratic procedures. We hope to address further this dichotomy in a future work.

Regarding (ii) special emphasis has also been put among economists concerning whether the monetary system should depend on a central monetary authority in the form of a Central Bank or should be decentralized, as was the case in Classical Athens. In the latter case, the functioning of the monetary system would be unregulated and automatic procedures for the good functioning of the system would prevail. The best hope for this to take place lies in cryptocurrencies. More specifically, their decentralized system favors pseudonymity, so illegal activity is enforced. Moreover, the decentralization of money enjoys some benefits such as lower transaction costs and much higher speed in transactions than usual (Böhme et al. 2015). Arguably though, the self-adjusted character of a monetary system impeded discretionary decision-making. This indicates that no precautionary measures could be taken in order to prevent crises and no easing measures could be employed in order to heal liquidity shortages and their severe consequences in today's high-leveraged financial systems.

This leads us to issue (iii), enumerated above. One of the major hopes for successful decentralization in monetary systems has been considered to be the Libra stable coin, which would enable extremely easy transactions via the Facebook platform, similar to sending a Facebook message using the "chatting" application. However, a number of important legislator impediments have prevented the Libra from being launched in June 2020 as was originally planned ${ }^{21}$. In close connection with the issue of decentralized monetary systems lies the potential of cryptocurrencies being considered "legal tender" by Central Banks. In principle, the decentralized character of cryptocurrencies is linked with the overall discussion regarding the decentralized mechanisms that were practiced in Classical Athens.

20 We owe to one of the referees the acknowledgment of the importance of issues (ii)-(iv) as potential further extensions to our analysis.

21 https://www.ft.com/content/23a33fcb-1342-4a18-be39-504e8507f752. 
It should be emphasized that such digital currencies could only serve one out of the three main functions of money. To be more precise, they could be employed as a means for transactions, although their lack of divisibility and their large nominal value in a number of cases prevents easy everyday use in relation to fiat money. Moreover, due to their highly speculative character as expressed by their extremely high levels of volatility they cannot serve as a unit of account or a store of value (Smith and Kumar 2018). Cryptocurrencies were initially planned for the purpose of being accessible to most of the global population and providing liquidity when national currencies fail; it is clear that their speculative character has attracted a lot of risky investors rather than ordinary economic agents. This innovative form of liquidity and investment is believed to satisfy great needs for liquidity but also lead to further debt accumulation -in the form of digital debt- and the constant demand for extra lax monetary policy.

Finally, regarding (iv), throughout the analysis of our paper it became understood that the value of the currencies in antiquity (and today) was, in principle, intrinsic - that is, commodity money. By contrast, the current financial establishment in the world economic system is based on fiat money and variable exchange rates. It is well-known that the disconnection of the US dollar from gold took place on 15 August 1971, as the US could no longer suffer the obstacles in credit creation that the linkage with gold reserves imposed. The US dollar not being tied with this precious metal has given eligibility for discretionary monetary policymaking and has fortified the country's defense against speculative attacks. Moreover, this has helped the US dollar to become the most internationally accepted currency as a means for transactions, as gold was more difficult to handle and could not adjust to altering conditions. It should be emphasized though that when untied with gold, the US dollar became less trustworthy for international transactions as it stopped being backed by the most precious metal.

By creating a synthesis of intertemporal financial issues between antiquity and today we believe (and hope) that we have created a significant impetus for further future research on related issues.

Author Contributions: Conceptualization, E.-M.L.E., N.C.K.; Methodology, E.-M.L.E., N.C.K., N.A.K.; Validation, N.C.K.; Formal analysis, E.-M.L.E., N.A.K.; Investigation, E.-M.L.E.; Writingoriginal draft preparation, E.-M.L.E. All authors have read and agreed to the published version of the manuscript.

Funding: This research received no external funding.

Institutional Review Board Statement: Not applicable.

Informed Consent Statement: Not applicable.

Acknowledgments: The authors are grateful to the referees for their comments and suggestions that lead to the further improvement of the overall argumentation of the paper.

Conflicts of Interest: The authors declare no conflict of interest.

\section{References}

Abbassi, Puriya, and Tobias Linzert. 2012. The Effectiveness of Monetary Policy in Steering Money Market Rates During the Financial Crisis. Journal of Macroeconomics 34: 945-54. [CrossRef]

Acton, Peter. 2014. Poiesis: Manufacturing in Classical Athens. Oxford: Oxford University Press.

Amemiya, Takeshi. 2007. Economy and Economics of Ancient Greece. New York and Abingdon: Routledge.

Aristophanes. 1994. Frogs. Translated by Matthew Dillon. Perseus Digital Library. New York: Routledge.

Bell, Stephanie. 2001. The Role of the State and the Hierarchy of Money. Cambridge Journal of Economics 25: 149-63.

Bergh, Andreas, and Carl Hampus Lyttkens. 2014. Measuring Institutional Quality in Ancient Athens. Journal of Institutional Economics 10: 279-310. [CrossRef]

Bitros, George. C., and Anastassios D. Karayannis. 2008. Values and Institutions as Determinants of Entrepreneurship in Ancient Athens. Journal of Institutional Economics 4: 205-30. [CrossRef]

Bitros, George C., Emmanouil M. L. Economou, and Nicholas C. Kyriazis. 2020. Democracy and Money Lessons for Today from Athens in Classical Times. London and New York: Routledge. 
Blamire, Alec. 2001. Athenian Finance, 454-404 B.C. Hesperia: The Journal of the American School of Classical Studies at Athens 70: 99-126. [CrossRef]

Böhme, Rainer, Nicolas Christin, Benjamin Edelman, and Tyler Moore. 2015. Bitcoin: Economics, technology, and governance. Journal of Economic Perspectives 29: 213-38.

Bresson, Alain. 2016a. The Making of the Ancient Greek Economy: Institutions, Markets, and Growth in the City-States. Princeton: Princeton University Press.

Bresson, Alain. 2016b. Aristotle and Foreign Trade. In The Ancient Greek Economy: Markets, Households and City States. Edited by Edward M. Harris, David M. Lewis and Mark Woolmer. New York: Cambridge University Press, pp. 41-65.

Butcher, Kevin, and Matthew Ponting. 2005. The Roman denarius under the Julio-Claudian emperors: Mints, metallurgy and technology. Oxford Journal of Archaeology 24: 163-97. [CrossRef]

Camp, John Mck, and John H. Kroll. 2001. The Agora Mint and Athenian Bronze Coinage. Hesperia 70: 127-62.

Christesen, Paul. 2003. Economic Rationalism in Fourth-Century BCE Athens. Greece E Rome 50: 31-56.

Cohen, Edward E. 1992. Athenian Economy and Society: A Banking Perspective. Princeton: Princeton University Press.

Constantakopoulou, Christy. 2007. The Dance of the Islands. Insularity, Networks, the Athenian Empire and the Aegean World. Oxford: Oxford University Press.

Demosthenes. 1939. Against Timocrates. Translated by A. T. Murray. Perseus Digital Library. Cambridge: Harvard University Press, London: William Heinemann Ltd.

Economou, Emmanouil M. L. 2020. The Achaean Federation in Ancient Greece: History, Political and Economic Organisation, Warfare and Strategy. Cham: Springer.

Economou, Emmanouil M. L., and Nicholas C. Kyriazis. 2017. The Emergence and the Evolution of Property Rights in Ancient Greece. Journal of Institutional Economics 13: 53-77. [CrossRef]

Elliot, Colin P. 2018. The Role of Money in the Economies of Ancient Greece and Rome. In Handbook of the History of Money and Currency. Edited by Stephano Battilossi, Youssef Cassis and Kazuhiko Yago. Singapore: Springer Nature Singapore Private Limited, pp. 1-20.

Engen, Darel T. 2005. Ancient Greenbacks, Athenian Owls, the Law of Nicophon, and the Greek Economy. Historia 54: 359-81.

Engen, Darel T. 2010. Honor and Profit: Athenian Trade Policy and the Economy and Society of Greece. Ann Arbor: Michigan University Press.

Figueira, Thomas J. 1998. The Power of Money: Coinage and Politics in the Athenian Empire. Philadelphia: University of Pennsylvania Press.

Finley, Moses I. 1973. The Ancient Economy. Berkeley: University of California Press.

Goetzmann, William N. 2016. Money Changes Everything: How Finance Made Civilization Possible. Princeton: Princeton University Press.

Günther, Joshua, and Felix Hahn. 2019. Choregia and trierarchy as profit-oriented entrepreneurships. Constitutional Political Economy 30: 177-93.

Habicht, Christian. 1999. Athens from Alexander to Antony. Cambridge and London: Harvard University Press.

Halkos, George, and Nicholas C. Kyriazis. 2010. The Athenian Economy in the Age of Demosthenes. European Journal of Law and Economics 29: 255-77. [CrossRef]

Hansen, Mogens H. 1999. The Athenian Democracy in the Age of Demosthenes. London: Bristol Classical Press.

Hansen, Mogens H. 2006. Polis: An Introduction to the Ancient Greek City-State. Oxford: Oxford University Press.

Harris, Edward. M. 2016. The Legal Foundations of Economic Growth in Ancient Greece: The Role of Property Records. In The Ancient Greek Economy: Markets, Households and City States. Edited by Edward M. Harris, David M. Lewis and Mark Woolmer. New York: Cambridge University Press, pp. 116-47.

Isocrates. 1980. Speeches: Panegyricus. Translated by G. Norlin. Perseus Digital Library. Cambridge: Harvard University Press, London: William Heinemann, Ltd.

Jarde, Auguste. 1996. The Formation of the Greek People. London and New York: Routledge.

Joyce, Michael, David Miles, Andrew Scott, and Dimitri Vayanos. 2012. Quantitative Easing and Unconventional Monetary Policy-An Introduction. The Economic Journal 122: 271-88. [CrossRef]

Kleiner, Fred S. 1975. Greek and Roman Coins in the Roman Agora. Princeton: The American of Classical Studies at Athens.

Kroll, John H. 1993. The Athenian Agora. Results of Excavations, XXVI. Princeton: The American School of Classical Studies at Athens.

Kroll, John H. 2011. The Reminting of Athenian Silver Coinage 353 B.C. Hesperia 80: 229-59. [CrossRef]

Kyriazis, Nicholas. 2009. Financing the Athenian State: Public Choice in the Age of Demosthenes. European Journal of Law and Economics 27: 109-27.

Loomis, William T. 1998. Wages, Welfare Costs and Inflation in Classical Athens. Michigan: Michigan University Press.

Lyttkens, Carl Hampus. 2013. Economic Analysis of Institutional Change in Ancient Greece. Politics, Taxation and Rational Behavior. London and New York: Routledge.

Mack, William. 2015. Proxeny and Polis: Institutional Networks in the Ancient Greek World. Oxford: Oxford University Press.

Mørkholm, Otto. 1991. Early Hellenistic Coinage from the Accession of Alexander to the Peace of Apamaea (336-188 BC). Cambridge: Cambridge University Press.

Morris, Ian. 2004. Economic Growth in Ancient Greece. Journal of Institutional and Theoretical Economics 160: 709-42. [CrossRef]

Ober, Josiah. 2008. Democracy and Knowledge. Innovation and Learning in Classical Athens. Princeton: Princeton University Press.

Ober, Josiah. 2015. The Rise and the Fall of Classical Greece. Princeton: Princeton University Press.

Rhodes, Peter J. 2005. A History of Classical Greek World: 478-323 BC. Oxford: Blackwell Publishing. 
Rhodes, Peter J., and Robin Osborne. 2003. Greek Historical Inscriptions 404-232 BC. Oxford: Oxford University Press.

Schaps, David M. 2004. The Invention of Coinage and the Monetization of Ancient Greece. Ann Arbor: The University of Michigan Press.

Smith, Christie, and Aaron Kumar. 2018. Crypto-Currencies-An introduction to not-so-funny moneys. Journal of Economic Surveys 32: 1531-59. [CrossRef]

Thonemann, Peter. 2011. The Maeander Valley: A Historical Geography From Antiquity to Byzantium. New York: Cambridge University Press. Tridimas, George. 2019. Democracy Without Political Parties: The Case of Ancient Athens. Journal of Institutional Economics 15: 983-98. [CrossRef]

Van Alfen, Peter G. 2011. Hatching Owls: Athenian Public Finance and the Regulation of Coin production. In Quantifying Monetary Supplies in Greco-Roman Times. Edited by François de Callatay. Bari: Edipuglia, pp. 127-49.

Williams, John C. 2011. Unconventional Monetary Policy: Lessons From the Past Three Years. FRBSF Economic Letter 31. Available online: https://www.frbsf.org/our-district/press/presidents-speeches/ (accessed on 3 October 2011).

Woolmer, Mark. 2016. Forging Links Between Regions: Trade Policy in Classical Athens. In The Ancient Greek Economy: Markets, Households and City States. Edited by Edward M. Harris, David M. Lewis and Mark Woolmer. New York: Cambridge University Press, pp. 66-89. 